\section{Intersections}

Canadian Journal of Music

Revue canadienne de musique
Intersections CANADIAN JOURAL OF MUSIC
REVUE CANADIENEE DE MUSIOUH

\title{
Hybridization and the Creation of "Third Spaces": an Analysis of Two Works by Tomás Gubitsch
}

\section{Alberto Munarriz}

Volume 30, numéro 2, 2010

URI : https://id.erudit.org/iderudit/1006379ar

DOI : https://doi.org/10.7202/1006379ar

Aller au sommaire du numéro

\section{Éditeur(s)}

Canadian University Music Society / Société de musique des universités canadiennes

\section{ISSN}

1911-0146 (imprimé)

1918-512X (numérique)

Découvrir la revue

Citer cet article

Munarriz, A. (2010). Hybridization and the Creation of "Third Spaces": an Analysis of Two Works by Tomás Gubitsch. Intersections, 30(2), 75-100.

https://doi.org/10.7202/1006379ar

\section{Résumé de l'article}

La récente recrudescence du tango a considérablement intensifié le rythme d'un long processus de " diffusion internationale » qui commence avec l'arrivée du genre à Paris pendant la première décennie du $\mathrm{XX}^{\mathrm{e}}$ siècle. Les nombreux dialogues engendrés par ce regain de popularité ont préparé le terrain pour une période de développement sans précédent marquée par la collaboration artistique, l'expérimentation et l'hybridation. En conséquence, le genre subit de nombreux changements, les nouvelles formes sonores qu'il revêt parmi les plus frappants de ceux-ci. À travers une analyse détaillée de deux compositions du guitariste et compositeur argentin Tomás Gubitsch, le présent document examine quelques-uns des processus qui façonnent actuellement la forme sonore de nombreuses variantes du tango. Ce travail devrait permettre de faire la lumière sur Gubitsch le compositeur et sur le phénomène présent du tango lui-même, ainsi que de contribuer à une meilleure compréhension des façons dont se construisent des hybrides musicaux.
All Rights Reserved (C Canadian University Music Society / Société de musique des universités canadiennes, 2011
Ce document est protégé par la loi sur le droit d'auteur. L’utilisation des services d'Érudit (y compris la reproduction) est assujettie à sa politique d'utilisation que vous pouvez consulter en ligne.

https://apropos.erudit.org/fr/usagers/politique-dutilisation/ 


\title{
HYBRIDIZATION AND THE CREATION OF “THIRD SPACES”: AN ANALYSIS OF TWO WORKS BY TOMÁS GUBITSCH ${ }^{1}$
}

\author{
Alberto Munarriz
}

Over the course of the last three decades, tango has shown a persistent and vibrant resurgence. This renewal has taken place not only in tango's home country of Argentina, but also elsewhere around the globe-Paris in particular. The current resurgence has greatly intensified the momentum of an already century-long, intercontinental dissemination of the genre. The cross-cultural and cross-musical dialogues promoted by tango's renewed popularity in recent years have set the stage for an unprecedented period of tango artistry, one marked by creative collaboration, experimentation, and richly productive mixings with other musical expressions and forms. As a result of this hybridization, the genre is undergoing numerous changes, among the most striking of which are the new sonic shapes tango is assuming. An investigation of these developments reveals that tango, in its current phase, is a highly flexible form of musical expression that, while capable of engaging and incorporating a range of outside musical influences and "non-traditional" components, is nevertheless able to retain a distinctive core of traditional identity. ${ }^{2}$

In this paper, I focus on a number of the musical influences-at times surprising and at times ambiguous - with which current tango has become, to borrow a phrase from Jocelyne Guilbault (2005), "audibly entangled." More specifically, I aim to discern the role played by these influences as well as to identify the musical elements (both structural and aesthetic) that allow for tango's current remarkable stylistic malleability. In order to facilitate these objectives, I concentrate on the works of one of current tango's most innovative contributors,

1 I am thankful to Patrick Boyle, David Lidov, and Michael Marcuzzi for their comments on an earlier version of this article. I also want to express my gratitude to Louise Wrazen for her guidance and support during the many stages of this ongoing research project. I am particularly thankful to Anne-Marie Gallagher; her editorial help immensely improved the final structure of this article. Finally, I want to thank Tomás Gubitsch for his help, unconditional support, and generosity.

2 In Argentina, the initial stages of tango's recent resurgence (mid-199os) have been initially characterized by a return to the aesthetic and compositional models that defined the style's golden years (1930s to 1950s). The resurrection of the orquestas típicas (typical orchestras), the traditional guitar trio, and the tango canción (tango songs) subgenre, along with the embrace of other referents of the "golden" period, draw attention to the complex relationship young Argentine musicians have had with tango's long-standing tradition (Luker 2007). In recent years, however, the work of a growing number of Argentine musicians has underlined the increasingly flexible nature of their relationship with the conceptual and aesthetics canon of tango. Their collaborative and explorative efforts have resulted in a period marked by an unprecedented stylistic diversity. 
the guitarist and composer Tomás Gubitsch. Gubitsch is one of many exiled Argentine musicians who, since the 1970s-the time of the country's notorious and brutal "Dirty War"- have resided in Paris. His musical life, begun as a teenager while still in Argentina, has involved a number of musical migrations and integrations, including experiences and experiments with such seemingly diverse and irreconcilable traditions as rock, tango, new music, and jazz.

For purposes of this paper, I centre my analysis on two of Gubitsch's tangos from the $2006 \mathrm{CD}$ entitled 5, a title chosen in reference to the fact that the tracks on the recording are performed by Gubitsch's quintet ${ }^{3}$ (see discography). The two works with which I am concerned here are, respectively, "Te acordás de mí?" (Do you remember me?) and "De los hermanos" (All things brotherly). These two works show the numerous and intricate compositional processes through which Gubitsch weaves in the sonic tapestry of his compositional output a number of idioms, musical traditions, and aesthetic conceptions conventionally disparate from the traditional Argentine tango ethos. In essence, Gubitsch incorporates into his music the defining characteristics of various forms as a way to articulate the eclectic nature of his musical conceptions within the stylistic framework of tango. In particular, I investigate the influences that jazz and free improvisation, Western art music, new music, minimalism, French impressionism, and rock have had on the conceptualization and subsequent materialization of "Te acordás de mí?" and "De los hermanos." By this investigation, I hope to shed light on Gubitsch the composer and on the current tango phenomenon itself, as well as to contribute to a better understanding of the ways musical hybrids are constructed.

In order to contextualize the musical analysis proper, ${ }^{4} \mathrm{I}$ begin the paper with a brief discussion of the history of tango and its hybridizing tendencies, this followed by a review of Gubitsch's biography.

\section{A Brief History of Tango and Its Hybridizing Tendencies}

The emergence of urban popular music genres such as tango and their subsequent creative and productive connection with other musics constitute a longlasting and prominent line of inquiry in musical scholarship. The products or offspring of such encounters have often been labelled musical "hybrids." Despite the fact that a great deal of debate has arisen in academic circles over the use of the term hybrid and related terms such as hybridity and hybridization,5 I find

3 Osvaldo Caló (piano), Éric Charlan (double bass), Sébastien Couranjou (violin), Tomás Gubitsch (guitar), and Juanjo Mosalini (bándoneon).

4 In general, I have approached the two compositions at the centre of this paper using methods of Western art music analysis. My first step was to spend a period engaged in close listening to the works. At the same time, I sketched a number of personal reactions, ideas, graphed representations, and comments. Next, I followed up on these initial impressions with an "analytical stage" in which I tested my impressions against the scores (generously supplied to me by Gubitsch himself) and developed a number of hypotheses. Importantly, I had the opportunity to further investigate my "armchair" assumptions with a period of fieldwork in Paris, during which time Tomás Gubitsch graciously granted me several interviews.

5 In order to inform their understanding of hybridity, many music scholars have looked to Homi Bhabha's The Location of Culture as a primary source. For example, in Grove Music Online, 
nevertheless the idea of the hybrid - at least in its loosest and most general sense of something being of mixed origin or composition-a useful working umbrella construct with which to approach many of the diverse kinds of interactions that tango has had with other forms of musical expression. Indeed, it is well known that tango itself emerged in the "in-between" or "third spaces" of competing cultural and racial differences (Bhabha 1994) that resulted from a number hybridizing tendencies in the New World. Thus, particularly in its dance form, it has been characterized as a transgressive genre (Carretero 1999; Collier 1992; Denniston 2007; Savigliano 1995), responsible for crossing lines (audible as well as bodily) and challenging social and musical boundaries. As Sarah Weiss has pointed out, "Thinking about hybridity and how we perceive it is important because it makes us think about boundaries, be they cultural or genre. It makes us question our expectations for and ideas about the nature of boundaries, in particular, what they mean both to us and to others" (Weiss 2008, 233). Following Weiss, the remainder of this section will "think about" some of the hybridizing entanglements that first generated tango as well as the subsequent boundary-breaking and cross-fertilizing turns it has taken since.

The initial formulation of the genre known as tango occurred in the mid to late nineteenth century in the increasingly thriving port districts of Buenos Aires and Montevideo. It proceeded as the result of a number of complex dialogic processes that had already begun to unfold during the second half of the century in social interactions between an itinerant indigenous population and a population of newly arrived European immigrants. In such a demographically heterogeneous context, culturally disparate choreo-musical traditions such as mazurkas, payadas, ${ }^{6}$ polkas, milongas camperas (rural milongas), habaneras, candombes, and waltzes were thrust into daily coexistence. By the end of the nineteenth century, through the reinterpretation and hybridization of these forms, tango emerged as a "third space" (Bhabha 1994) for the negotiation of struggles to structure racial, sexual, and class identities in the River Plate. For the majority of cultural elites at the time, however, particularly those in Buenos Aires, tango was considered shockingly if not despicably transgressive.

Martin Stokes, author of the entry on ethnomusicology, underlines the importance of Bhabha's contribution: "Hybridity and creolism are crucial aspects of global cultural consciousness, not in the sense that their origins are 'no longer' pure (since no culture's origins are or can be), but in the sense that they engender new forms of relativizing self-consciousness, of being neither here nor there, 'us' or 'them,' but being in-between, in a 'third space"' (Bhabha 1994). Thus Stokes carefully sidesteps a number of voices in post-colonial studies and related fields who have criticized proponents of hybridity theory. The criticisms have included accusations of being "elitist" (e.g., hybrid as a pejorative term connoting the idea of "mongrel"), "illogical" (e.g., there cannot be a hybrid unless two "pure" identities generate it initially), and ultimately "essentialist" or purist when what they claim to be is "antiessentialist." As Frello (n.d., 1), puts it, they have been seen as "reproducing the very idea of cultural purity that they are meant to transcend." Hybridity also entails a number of other terms and concepts, including transgression, diaspora, Creolization, transculturation, syncretism, mestizaje, cannibalism/anthropophagy, and dialogic/polyphony/multivocality (Bakhtin 1981; Bhabha 1994; Canclini 1995; Kapchan and Turner Strong 1999; Nederven Pieterse 1995; Young 1995).

6 Originally from South America, the payada is a style in which the payador sings improvised poetry to his own guitar accompaniment. 
Not long after its emergence in South America, tango made its first trip to Europe. No one knows for sure if it was in the port of Marseilles in 1905 or in Paris's Butte-Montmartre a few years later where tango first landed. Neither is it certain if it was sailors aboard the Argentine frigate Sarmiento, vacationing Argentine beef barons, or the early tango musicians sent to Paris by the Gath $y$ Chavez company to record who first took the Argentine tango tradition to the Continent. Despite the uncertainties and myths surrounding the emergence and evolution of early tango, we do know that by 1910, the genre was firmly settled in Paris (Cadicamo 1975; Humbert 2000; Zalko 2001).

Tango's arrival to Paris would be a pivotal moment in the evolution of the genre. The sweeping success that followed tango's arrival in the French capital placed the "seal of approval" that the Europeanized elites of Buenos Aires needed in order to accept and embrace the "lascivious" dance they previously despised. In Parisian salons, Argentine tango had been divested of its "vulgar" contortions and stylized into a "legitimate practice" that the aristocracy of Buenos Aires was subsequently ready to reclaim as theirs. This re-appropriation has often been interpreted as the event that opened the door for tango's final popularization in its native Buenos Aires. ${ }^{7}$ While one cannot overlook the significance of this event, seeing the genre's final popularization as a direct consequence of its success among the city's elites presents an uncritical interpretation that, as a number of scholars have recently pointed out, leaves numerous issues unexamined (Cibotti 2009; Collier 1992; Garramuño 2007; Savigliano 1995). Most saliently, it bluntly disregards the deep-seated social, political, and cultural changes brought by the city's radical demographic change and exponential economic growth during that period (Cibotti 2009; Sarlo 1999). For this examination, it suffices to recognize that, at least for some, tango "sounded" different after having conquered the French capital.

When undertaking a musicological analysis of the genre, however, the long "international dissemination" (Pelinski 2000a, 2008) that followed the arrival and subsequent success of tango in Paris becomes significantly more relevant. While interrupted during both world wars, tango's international dissemination has continued with increasing momentum. In his 2008 article, Ramón Pelinski periodizes this process into three main stages, each defined by its respective historical and political contexts and tango's own sonic evolution. Following Pelinski, the first stage roughly coincides with La belle époque. It began with the arrival of tango in France and ended with the beginning of the First World War. The second one, bracketed by both armed conflicts, corresponds with Les années folles. The last wave in tango's international dissemination began in the late 1970s, primarily as a response to Argentina's catastrophic socio-political situation, about which Marta Savigliano writes, "In the 1970s and 1980s a battered generation took hold of tango as an expression of the experiences of political terror and exile lived during the most recent military government (1973-1983). As a result, tango went through a revival in Europe and some sensitive argentino

7 The idea of "reappropriation" has been previously used by Marta Savigliano and Florencia Garramuño (Garramuño 2007; Savigliano 1995). 
artists and astute impresarios launched successful shows in the United States, Japan, and Buenos Aires" (Savigliano 1995, 12).

The consequences of this dissemination went far beyond placing tango on the international stage. Tango began to emerge around the globe, moving rapidly from Paris to London, Barcelona, Berlin, Helsinki, Rotterdam, New York, Montreal, Tokyo, Istanbul, and numerous other urban centres, until now tango is no longer simply "imported" for consumption but also locally conceptualized, produced, and commercialized.

From a musical perspective, the most significant outcome was the emergence of stylistic variants whose conceptualization and development were defined by the cultural dialogues particular to each of tango's new socio-cultural contexts. ${ }^{8}$ Sensitized by these dialogues, tango began a series of musical and semantic transformations. Since the 1990s, the changes brought by globalization have had a profound impact on the nature and pace of the dialogues shaping these contemporary tangos. As Martin Stokes writes, the accelerated transnational movements of people, capital commodities, and information has energized and cross-fertilized music-making in the diasporas in the major urban centres of Western Europe, North America, and elsewhere (Stokes 2004), and tango music-making has been no exception.

Thus, cross-cultural dialogues and hybridization are not new to tango, a genre whose own birth resulted from the mixing of traditions. While in each instance the hybridization evolved according to distinct sets of social actors, geographic locations, musical traditions, cultural contexts, and political circumstances, in all of them the result has been conceptually similar. Hybridization produced a new style, tradition, or genre in its own right, thus occupying a "third space" that, in the words of Homi Bhabha, contains "something different, something new and unrecognizable, a new area of negotiation of meaning and representation" (Bhabha 1994). Despite the sometimes seemingly irreconcilable contexts for these convergences of traditions, conceptually similar hybridizations can also be recognized behind the emergence of the newer textures introduced by Astor Piazzolla and Eduardo Rovira in Buenos Aires during the 1950s, Rodolfo Mederos in the 1970s, the Beytelmann-Caratini-Mosalini trio in the 1980 , or the recent works of Diego Schissi.

As we can see from this overview, "non-traditional" elements have reconceptualized tango throughout its history. Despite these hybridizing antecedents, seldom in tango's history has such a wide range of influences been given structural, syntactic, and aesthetic weight as in the contemporary examples analyzed below. As my analysis suggests, the hybridization now shaping the many voices of tango needs further and careful consideration if we are to understand their socio-cultural role and semantic potentiality.

8 The concepts of de-territorialization and re-territorialization were first applied in the study of tango by Ramón Pelinski in his seminal work Tango Nómade (Pelinski 200oa). 


\section{TOMÁs GUBITSCH: L'ENFANT TERRIBLE}

Tomás Gubitsch was born in Buenos Aires in 1957. At age seventeen, already a guitar virtuoso, he joined Luis Alberto Spinetta's group, Invisible. The group became one of the most influential ensembles in the history of Argentina's so-called rock nacional movement, a musically oriented social movement that, according to Pablo Vila, built its strongest identity during the dictatorship of the 1970 and, as part of its political-cultural agenda, made a commitment to experimenting with all kinds of hybrid musical crossovers (Vila 1989). ${ }^{9}$ Gubitsch's remarkable work as a lead rock guitarist can be heard on Invisible's seminal 1976 album, El jardín de los presentes (The garden of those who are present).

At around the same time as his engagement with Spinetta, Gubitsch was called by bandoneón player Rodolfo Mederos to join Generación Cero, one of the earliest attempts by an Argentine ensemble to fuse elements of jazz, rock, and tango. Generación Cero's first album, De todas maneras (roughly translated as "In any way," or "In all possible ways," 1977), documents the musical maturity of the eighteen-year-old guitarist. Later in 1977, when Astor Piazzolla assembled a second version of his Octeto Electronico (Electronic octet) for a European tour, Gubitsch was called to perform as the octet's guitarist. With the tour over and as a consequence of Argentina's disastrous political situation, Gubitsch along with other members of the band decided to stay in Paris. Once settled, he began what would turn out to be an exceptionally prolific career, recording, composing, and arranging for artists such as Stéphane Grappelli, Steve Lacy, Naná Vasconcelos, and Michel Musseau, among many others. He has scored numerous films, composed an opera-ballet, and today can often be seen conducting La Orchestre de Bretagne and the New Japan Philharmonic Orchestra. One of his latest works is a concerto for four double basses, commissioned by the French government.

The various traditions, styles, and aesthetic inclinations Gubitsch has worked with over the years attest to the highly multifaceted nature of his career and musical output. He is clearly committed to creating novel forms of musical expression, and he embraces possibilities for new kinds of fusion and blending. As he explains in the liner notes that accompany the CD entitled 5 , "Composing or playing within the context of a specific genre means having to respect certain aesthetic traditions and styles, but it also involves casting off our imaginative moorings. More than this, I would say that certain genres of music are provocative; if these are not in constant motion, constantly evolving, or if they content themselves with self-imitation, they end up ossified, like museum pieces" (Gubitsch 2006).

9 According to Pablo Vila, "Strictly speaking, rock nacional, in musical terms, is music of fusion ... what distinguishes rock nacional are the ingredients of the blend. Throughout its history, the rock nacional movement has established varying relationships (depending on the period and the musician) with rock 'n' roll, blues, pop, symphonic rock, punk, jazz, jazz-rock, American country, American folk, heavy metal, new wave, reggae, ska, rockabilly, classical music, protest music, bossa nova, samba, tango, and Argentine folk music. All these relationships are codified and decodified as rock nacional, an intriguing phenomenon connected to the problem of defining a genre" (Vila 1989, 3). 
Underlining Gubitsch's creative and progressive outlook is a brief publicity piece for the RootsWorld website: “Tomás Gubitsch is the global village personified, a polyglot international fusion on two legs. His career since achieving fame as a youthful rock star in Buenos Aires reads like an adventure serial, full of unexpected journeys, encounters of various kinds, close calls and radical changes" (Roden n.d.).

Such a description allows us a preliminary appreciation of the kinds of dialogues we might expect to encounter when we listen to Gubitsch's music to understand how his hybrid sensibilities inform the evolution of tango variants.

At this point, it is important to caution that, although they are certainly part of the current tango revival, Gubitsch's works cannot be taken as necessarily representative of the many different compositional trends that within the genus tango have developed in Europe. For example, Gubitsch's aesthetic conceptions seem unrelated to Juan José Mosalini and Gustavo Beytelmann's chamber escapades, Marcelo Nisinman's explorations, or Gerardo Jerez Le Cam's Balkan-influenced conceptualizations. Nonetheless, the characteristics that my analysis of "Te acordás de mí?" and "De los hermanos" will expose indicate a broader sensibility common to a large number of composers working with tango outside of Argentina.

\section{GUBITSCH'S IMPROVISATION AND THE INFLUENCE of JazZ and Western Art Music ${ }^{10}$}

“Te acordás de mí?," the first track on Gubitsch's 2006 CD 5, opens with a threeminute solo guitar introduction developed around thematic elements of the main piece. Structurally, the characteristic features of this introductory segment allow us to interpret it in the vein of a musical prelude in the classical or baroque sense. Gubitsch's playing is virtuosic, highly idiomatic, and rhythmically free. In essence, the overall function of the segment is to attract the listener's attention and define the B-minor tonality of the piece. Beyond its structural function, however, this opening section presents a number of remarkable qualities.

First, in contrast to the usual convention, Gubitsch presents the guitar in a role of unusual melodic prominence. Traditionally, none of the voices of a small instrumental tango ensemble are given leading importance. In traditional arrangements, the violin, guitar, bandoneón, and piano take turns articulating leading melodic passages. Despite the marked stylistic differences between the works of pioneering ensembles such as Aníbal Torilo's Cuarteto Tipico, Horacio Salgán’s quintet, or the Sexteto Mayor, they all present clear examples of this "turn-taking" aesthetic approach. It is primarily after the appearance of the small ensembles of Astor Piazzolla and Eduardo Rovira in the 1950s that

10 A live video-recording of Gubitsch's Te acordás de mí?, recorded by the same ensemble that registered the version on which I have based this analysis, is available at http://www.dailymotion.com/ video/xyef9_tomas-gubitsch-te-acordas-de-miy_music. Similarly, the version of De los hermanos used as the basis for this work can be heard on My Space at http://www.myspace.com/tomasgubitsch. 
compositions began to be conceptualized and developed around a chief voice: at that time, the characteristic voice of the bandoneón.

In Gubitsch's case, the fact that within the context of a quintet an electric guitar is presented as a prominent melodic voice right from the beginning of a piece is an early indicator of the composer's interest in an artistic conception that is undoubtedly influenced, although not regimented by, tango's previous aesthetic traditions (e.g., orquesta típica [typical orchestra], traditional quintet, Astor Piazzolla's Nuevo Tango). It is important to note, however, that the prominence of the guitar is not maintained throughout the entire album. Other than during the prelude to "Te acordás de mí?" and other short segments where Gubitsch's guitar shines, instrumental textures are carefully balanced. Interestingly, when asked about the relationship between the guitar and the rest of the ensemble, Gubitsch explained that, overall, he does not conceptualize his instrument as having a preponderant position in the quintet: "It is actually a matter of redistributing the roles within the quintet, in fact, to decrease the usual central character of the bandoneón."11

A second quality of the introduction to "Te acordás de mí?" identifies it as remarkable. Its arrangement is clearly planned, but its rhythmically loose articulation and the emergence of unexpected melodic spurts hint at a renewed interest in the textural possibilities offered by improvisation, as this piece, and other compositions on 5, later confirms. It is impossible to ascertain the role that each musical tradition found cohabiting in Buenos Aires at the end of the nineteenth century (e.g., mazurkas, habaneras, payadas, polkas, milongas, and candombes) played in determining tango's initial shape. Nonetheless, it is possible to imagine the role that improvisational practices would have had in channelling their interaction. During tango's early stages (1870s-1920s), improvisation was its main interpretative practice; tangos were played a la parrilla (on the grill; a reference to the stand where the lead sheet would have been placed). About this particular performative approach, Ramón Pelinski writes, "In fact, the tradition of playing a la parilla (meaning, with a random instrumentation and without written parts for each instrument) is still in vogue today, especially in evening parties where musicians gather to accompany a milonga (a venue or occasion where tango is danced)" (Pelinski 200ob, 27). ${ }^{12}$ It is due in part to the subsequent enlargements of the tango orchestras and the increasing complexity of their arrangements (1930s-1940s) that improvisation progressively fell out of favour. Later, in the smaller ensembles characteristic of the 1960 s and early 1970 , improvisation regained prominence and grew more audacious, although the composition's main melody was always kept in earshot.

11 "Para mi, la guitarra no es tan preponderante, se trata mas bien de redistribuir los roles en el quinteto y, de hecho, de sacarle cierto protagonismo al bandoneón" (email to author, 2 September 2008 , all translations are the author's).

12 "En efecto, la tradición de tocar a la parilla (es decir, con una distribución instrumental improvisada, sin partes escritas para cada instrumento) todavía esta viva hoy, sobre todo en las veladas donde los músicos se reúnen ocasionalmente para acompañar una milonga (el baile del tango en determinados sitios del barrio)." 
Gubitsch's use of improvisation contrasts sharply with the "traditional" approach described above. In the piece under analysis here, improvisatory passages, whether played by Gubitsch or the other members of the quintet, are verbose, agile, and dense. At moments, the players' improvisations on "Te acordás de mí?" are even reminiscent of the "sheets of sound" approach commonly associated with John Coltrane.

In 1958, Ira Gitler coined the term "sheets of sound" as a metaphorical reference to the specific changes that defined Coltrane's improvisational approach at the time. Coltrane, Gitler wrote, "has used long lines of multitoned figures within these lines, but in 1958 he started playing sections that might be termed 'sheets of sound"' (Gitler 1958, 44). Beyond their bombastic effect, when expertly manipulated, these dense vertical patterns can have what Gitler insightfully defined as a "cumulative emotional impact, a residual harmonic affect" (44).

In "Te acordas de mí?," the initially idiomatic guitar solo in the introduction rapidly evolves into a concatenation of lightning-speed lines that elevate the overall tension of the section and propel the momentum of the piece forward with unexpected force. In "De los hermanos," the seventh track on 5, the solo section is structured as a dialogue between Juanjo Mosalini's bandoneón and Gubitsch's guitar. Mosalini opens with an abrupt and sharply articulated melody that emulates the syncopated structure of the piano and bass accompaniment but that is carefully phrased in order to avoid overlapping with the rhythmic structure. In fact, by articulating the bandoneón precisely during gaps in the accompanimental grid, Mosalini interweaves a rhythmic counterpoint to the piano and bass that creates an explosive drive. Predicting perhaps the inefficacy that a rhythmic-based counterstatement would have in such a dynamic opening, Gubitsch chose instead to unleash a stream of fiercely phrased lines, a "sheets of sound" counterstatement carrying all the expressive and emotional potential noted by Gitler in reference to Coltrane.

To suggest the influence of jazz here is both tempting and probably accurate. But the suggestion becomes rapidly inappropriate when we are confronted with the binary, not swung, nature of tango's rhythmic articulation. Gubitsch sees binary rhythmic articulation as a quintessential characteristic of tango. It is important to remember that early and traditional jazz (e.g., swing, bebop, hardbop) are characterized essentially by the predominant triple subdivision of the quarter-note, a rhythmic approach that gives jazz its typical "swing" feel. Contrarily, since its beginning stages, tango's rhythmic articulation has been characterized by a binary subdivision of the beat, a trait that also defines musical traditions that likely informed tango's initial developments (e.g., candombe, habanera, Spanish tango or zarzuela). It is difficult to substantiate the exact relationships that appear to exist between tango's early stylistic traits and those that define its musical antecedents (Kohan 2002; Lamas and Binda 1998; Matamoro 1971; Thompson 2005; Vega 2007). Indeed, there are numerous elements-including extant musical traditions, dances, and cultural migrations-that would have to be carefully analyzed in order to trace the origins of tango's binary rhythmic articulation. Nonetheless, the task can be simplified by observing the relationship between the rhythmic scheme most commonly 
associated with tango and the patterns that defined the rhythmic accompaniment of the Cuban habanera (see fig. 1).
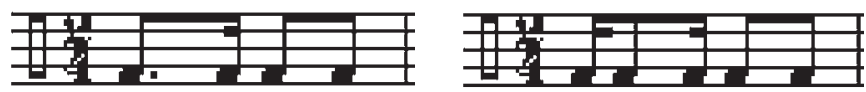

Figure 1. Traditional accompaniment patterns of early tango.

It is beyond the scope of this article to analyze the processes that defined tango's initial shape and subsequent development. However, it is important to keep in mind the intrinsic nature of the genre's binary subdivision. In conjunction with the rhythmic and harmonic frameworks adopted by early tango musicians, the binary subdivision defined tango's initial melodic articulation, phrasing, and accentuations. Perhaps most importantly, the binary approach defined the way in which the genre's distinguishing patterns of syncopation developed. In a conversation in January 2008, Gubitsch suggested to me that tango's binary subdivision is related to a pulsación de base (fundamental pulsation) in the genre. Only by undertaking the analysis that follows here have I been able to grasp the full extent of what Gubitsch meant. The pulsación de base that he was referring to is, in fact, the product of the complex interaction between the numerous elements that together define the performative attitude that characterizes the genre-all of which rest on its binary subdivision.

Because of the differences in their intrinsic articulations (i.e., triple subdivision of the quarter-note versus binary subdivision of the beat), to suggest the influence of jazz upon Gubitsch is thus problematic. Structurally, however, such an influence seems more possible. In "De los hermanos," for example, the bandoneón solo section evolves through a scheme of improvisation commonly employed by jazz players. In this section, the bandoneón and guitar do what in jazz argot is referred to as "trading," which is the division of the chorus between or among solo players, each of whom takes in turn a phrase of equal temporal length. Initially, the bandoneón and guitar exchange phrases of eight measures. Then the ratio of trading is reduced by half, such that each instrument takes four measures. In addition to an increasing melodic thrust, the acceleration in the rate of textural change enhances the momentum even further.

When I shared these findings with Gubitsch, after he agreed with the stylistic relationships I had established, he added that from a structural viewpoint, his use of improvisation has closer ties to the classical tradition than to jazz. In effect, looking beyond the elements that have allowed us to pin down jazz as a significant influence on "Te acordás de mí" and "De los hermanos" and concentrating instead on how the relevant sections have been worked into the pieces' overall structure, we realize that, in functional terms, their role contrasts sharply with structural roles traditionally played by such section in an original jazz composition.

Throughout most of jazz history, compositions or "tunes" consisting of a melody and an underlying harmonic progression have been vehicles for solo 
improvisations. In his seminal publication, Thinking in Jazz, Paul Berliner attests, "It has become the convention for musicians to perform the melody and its accompaniment at the opening and closing of a piece's performance. In between, they take turns improvising solos within the piece's cyclical rhythmic form" (1994, 63). In contrast, the solo sections in "Te acordás de mí?" and "De los hermanos" are short and evolve over selected harmonic segments of the works. In addition, despite the "sheet of sound"-like passages, these solos maintain a carefully preserved thematic relation with the composed sections that precede or follow them. In truth, these attributes point to a tango conceptualization that shares marked similarities with the structure of the solo passages of the classical concerto.

\section{“Ambiguous” Interpretations AND Rhythmic ANCHORAgE}

During one of our conversations, Gubitsch mentioned that, as a composer, he finds one of the most attractive characteristics of tango to be its rhythmic ambiguity. For him, ambiguity identifies most urban musics (e.g., rock, flamenco, jazz, tango). But it does not point to vagueness. If there is something indistinct or unclear in these musics, it is certainly not their rhythmic schemes. For Gubitsch, ambiguity points instead to the almost omnipresent possibility of there being two or more coexisting interpretations of a given rhythmic articulation. I introduce this idea of ambiguity in my analysis here because, if the solos just described in the section above were to be isolated from their underlying accompaniment, one would have serious difficulties associating them with a particular style. In most cases, a soloist's articulation of a given line, considered together along with its particular timbre, would provide us with a relatively clear idea of the underlying style of the given composition. In the case of "Te acordás de mí?" and "De los hermanos," however, the relationship is not so easily established. In "Te acordás de mí?" the soloing is stylistically closer to traditional tango than in "De los hermanos." In both instances, however, what finally anchors the solos within the realm of tango is not the improvising voice but the rhythmic design of the ensemble's underlying accompaniment.

The solo in "De los hermanos," a piece written in E minor, progresses largely over dominant minor territory (B minor), and it is articulated over a repeated two-bar rhythmic pattern (see fig. 2). The 3-3-3-2-3-2 breakdown of the pattern (further broken into 3-3-3-2-1-2-2) emulates the rhythmic scheme of the piece's opening two-bar figure (see fig. 3 ). ${ }^{13}$

Something similar occurs in the solo section of "Te acordás de mí?" Here the accompanying pattern is, in fact, an expansion of the 3-3-3-3-2-2 scheme that shapes the opening melody. As shown in figure 3, Gubitsch modifies the rhythmic pattern by interpolating an extra measure (silent for the first half of the solo section) after each of the eight measures of the phrase. In formal terms, the insertions widen the soloist's field of action while retaining the grounding force of the now-severed opening riff. Concurrently, a significant timbral and consequent expressive change is effected by the manipulation. The momentary

13 All reductions and transcriptions are the author's. 
fade-outs of the supporting ensemble bring the soloing voice to the fore, thus magnifying its expressive power.

Designing an ensemble's accompaniment for the solo or solo-like sections of a composition according to the defining rhythmic traits of the work's main theme is a technique widely used in many styles (e.g., chamber music, jazz, progressive rock, blues). It grants the soloist or composer a great deal of freedom while enhancing the listener's perception of cohesion between sections. What is most significant in "Te acordás de mí?," however, is not the particular technique employed, but the actual patterns used. These patterns are all developments of the traditional 3-3-2 rhythmic scheme adopted in the mid-1920s by tango composers such as Julio de Caro and Francisco Canaro, the origins of which can be traced back to the 3-1-2-2 scheme of the eighteenth-century Cuban habanera and the subsequent 3-2-2 reinterpretations that later shaped the slow Argentinean milonga (see fig. 4).

These 3-3-2 variants are certainly not Gubitsch's. Astor Piazzolla generalized the usage of various mutations of the 3-3-2 pattern to the point of making them his personal stylistic mark. As Gabriela Mauriño points out, "Piazzolla took his rhythmic treatment from the orchestras of Julio de Caro and later Alfredo Gobbi, among others, systematizing its usage until turning it into a trait distinctive of his style"14 (Mauriño 2001, 242). Figures 5.1-5.4 shows a few melodic excerpts that exemplify Piazzolla's manipulation of the 3-3-2 pattern.

In light of these excerpts we see that, as a composer, Gubitsch is relying on one of the most traditionally manipulated elements of tango in order to anchor his solos within it. At the same time, the novel progressions, textures, and melodies that he masterfully combines allow him to avoid stepping into numerous Piazzolla-like clichés.

Let us return momentarily to the pattern used to structure the accompaniment under the solo in "De los hermanos" (see fig. 2). The segment was previously examined in relation to the composition's opening motif. In fact, I interpreted it as a "distillation" of the motive. As we saw, Gubitsch established this relationship to frame the melodic and harmonic liberties characteristic of an improvisatory section within the particular identity of the composition. As described above, however, this relationship does not capture the "distillation" in full. Further examination of the segment unearths an unforeseen insight into the complexities of the composer's musical designs.

As shown in figures 2.1 and 2.2, the accentual schemes of the opening twobar motif and the accompaniment pattern in "De los hermanos" are similar but not equal; their second bars are not structured in similar manner. When analyzing the second bar of both patterns, we see that in contrast with the opening motif, where the sixteenth-notes (corresponding to the second, fifth, and eight eighth-notes) are accented, in the accompaniment, the sixteenth-notes (corresponding to the second, fourth, and sixth eighth-notes) are dynamically accentuated. As it stands, in most analytical observations, this discrepancy would

14 "Piazzolla lo tomó de las orquestras de Julio De Caro y más tarde Alfredo Gobbi, entre otras, y sistematizó su uso de tal forma que lo convirtió en un rasgo distintivo de si estilo.” 


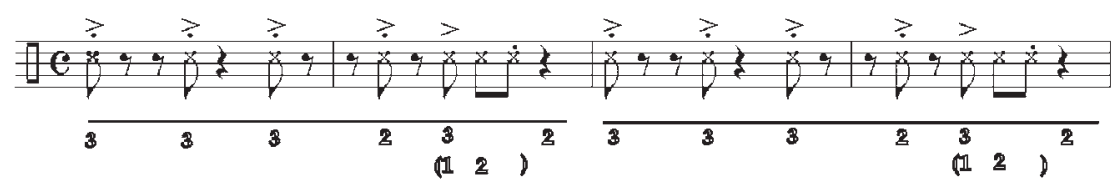

Figure 2.1. Tomás Gubitsch, "De los hermanos": rhythmic reduction of the accompaniment pattern.

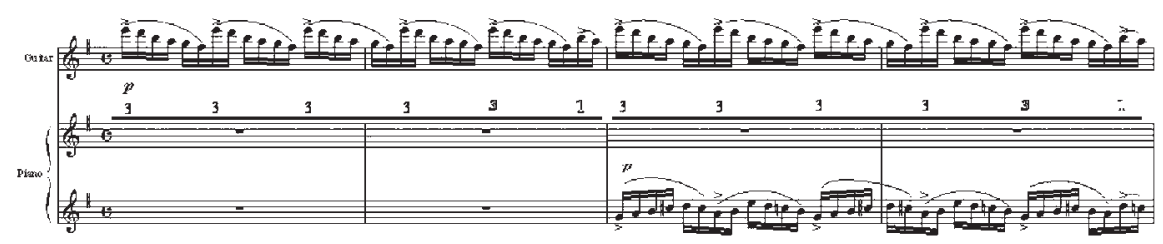

Figure 2.2. Tomás Gubitsch, "De los hermanos," mm. 1-4.

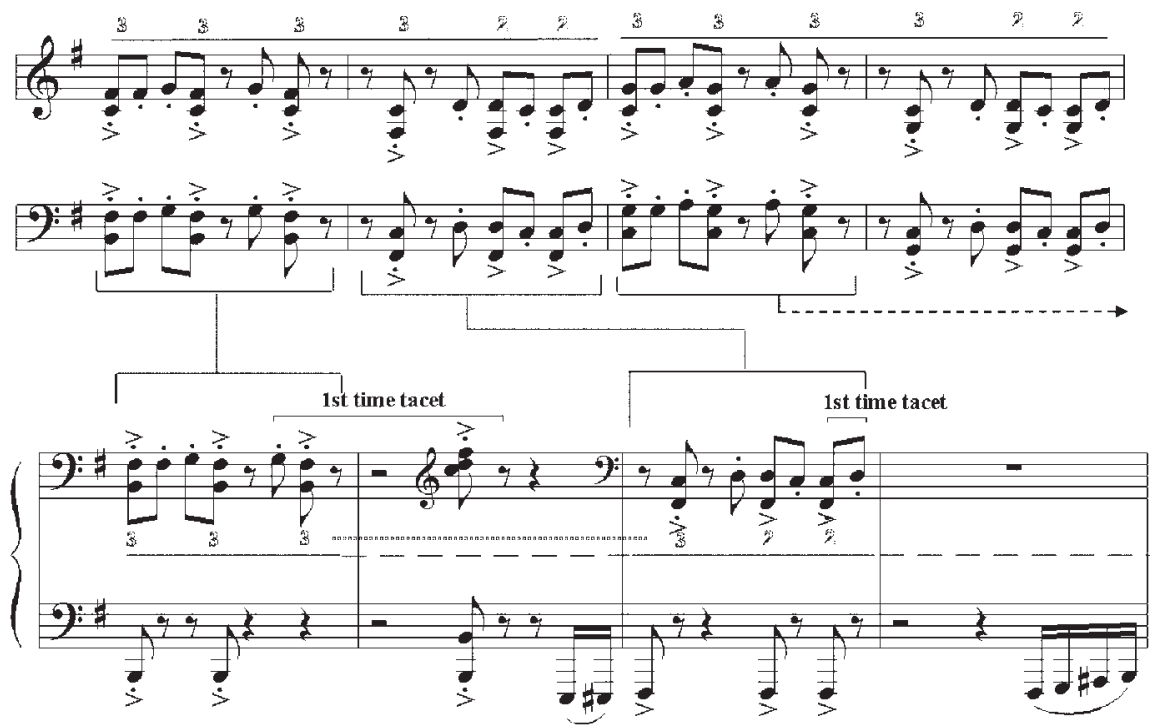

Figure 3. Tomás Gubitsch, “Te acordás de mí?”: concordance between accompaniment under guitar solo and opening riff.

be overlooked or interpreted as merely ornamental. It is not until an additional element of the composition - the rhythmic design of its main theme-is taken into consideration that the possible interpretation of the accompaniment pattern as a "distillation" of some of the piece's defining characteristics can be seen as effectively reinforced. Figure 6 presents a graphed concordance to make visually evident the correlations between the opening motif, the main theme, and the accompaniment pattern. 
The metrical alignment of the segments allows us to interpret the rhythmic design of the accompaniment pattern as a carefully crafted sum of the rhythmic skeletons of the main theme and the opening motif.

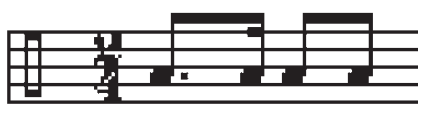

Figure 4.1. Habanera and early tango.

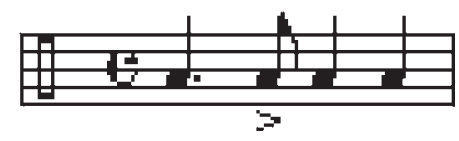

Figure 4.2. Fast milonga.

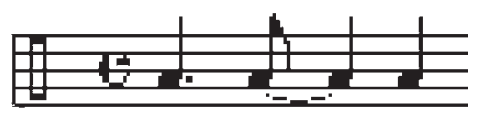

Figure 4.3. Slow milonga.

Figure 4. Basic 3-3-2 rhythmic schemes.

Up to this point, identifying the numerous stylistic ingredients informing the conception of Gubitsch's tangos has hinged primarily on the recognition of a number of procedures and techniques whose stylistic lineage remains easily recognizable, despite their affected manipulations. The structural setting of the improvisational passages, the instrumental "trading" used to articulate them, and some of their aesthetic characteristics are indisputable signs of the composer's interest in jazz. Similarly, the rhythmic arrangements used to articulate the accompanying thrust for those improvisatory segments expose the composer's relationship with the Piazzollean tradition.

The manipulations described in figure 6, however, point to a degree of thematic condensation and compositional organization that strikes us as foreign when interpreted within traditional tango. In fact, such an approach seems more in accordance with the structural frames of a work tied to the Western concert tradition, and the nuances characterizing the segment in figure 6 are certainly suggestive. However, for me to suggest the influence of the Western art tradition is grounded primarily on my knowledge of the long-standing relationship Gubitsch has had with it. In order to fully grasp the role that Western art music styles have had in shaping Gubitsch's musical designs in "De los hermanos" and "Te acordás de mí?," it is important to analyze other segments of these compositions. Such an exercise reveals an important connection with minimalism and French impressionism. 


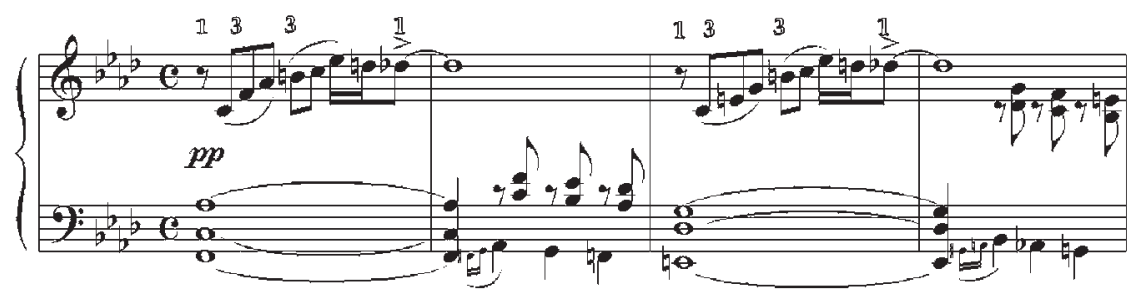

Figure 5.1. Astor Piazzolla, “Adios Nonino," mm. 1-4.

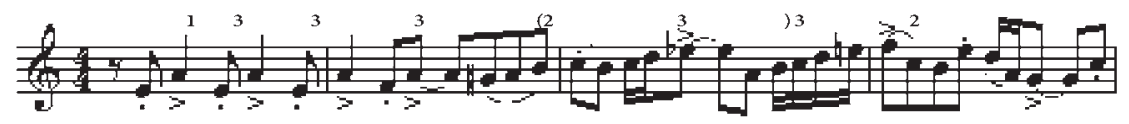

Figure 5.2. Astor Piazzolla, "Muerte del Angel," mm. 1-4.

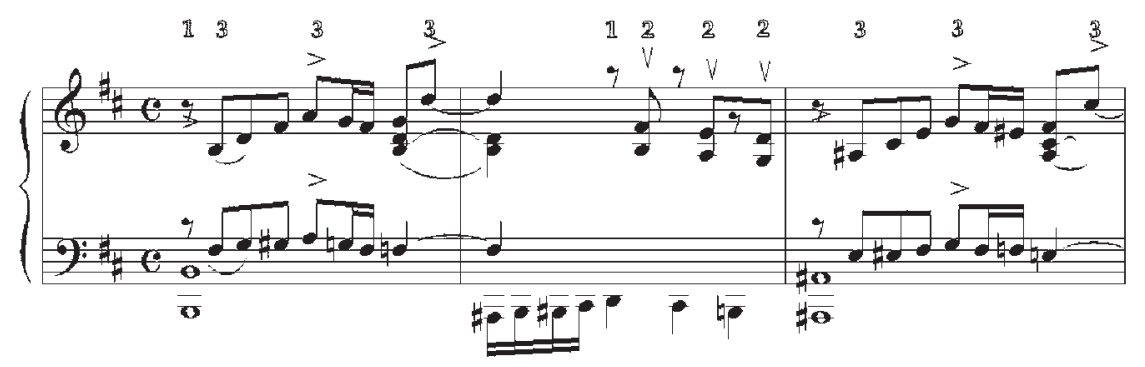

Figure 5.3. Astor Piazzolla, "Verano Porteño," mm. 9-11.

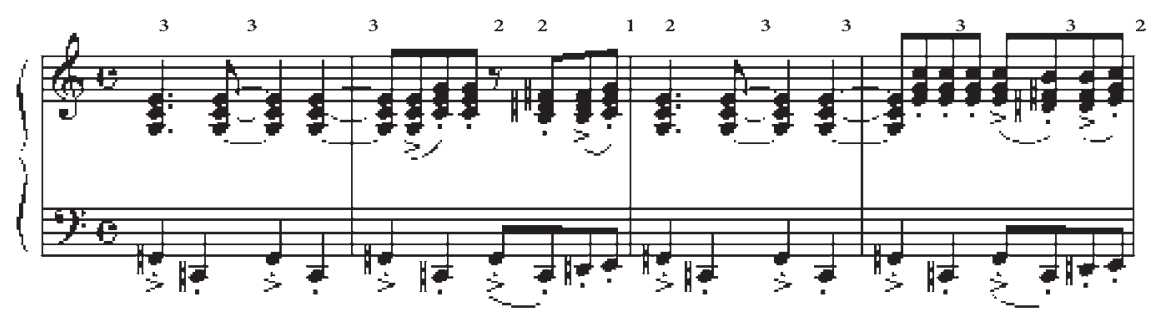

Figure 5.4. Astor Piazzolla, “Contrabajisimo,” mm. 75-78.

Figure 5. Examples of Piazzolla's manipulation of the 3-3-2 rhythmic scheme in four of his compositions.

\section{Minimalism}

As I have previously mentioned, tango is one among many of Gubitsch's compositional interests. It may, in fact, be the one least consciously represented in his artistic output. During one of my conversations with him, he mentioned that people have said to him numerous times that they thought they had recognized some tango elements in his "new music" compositions for film and in other contemporary works. He explained that he has often been surprised by such observations, since he was unaware of having used such elements. However, if tango elements have in fact "sneaked into" the composer's new music 


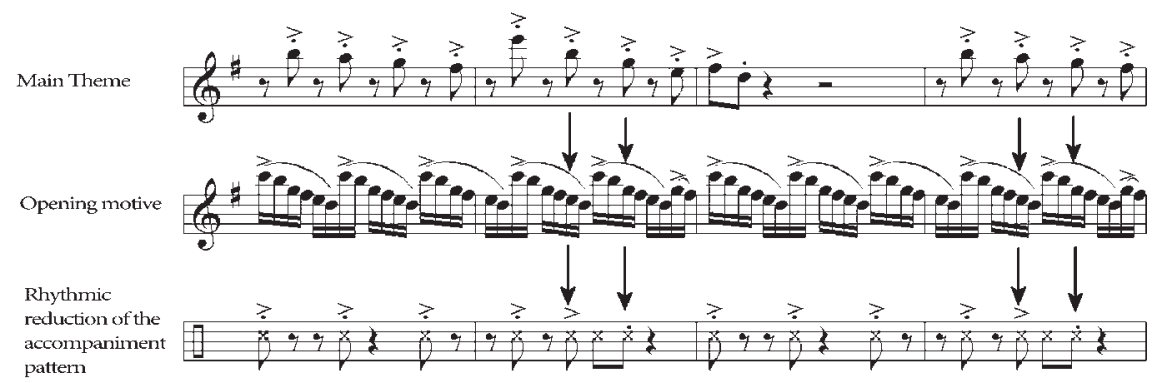

Figure 6. Tomás Gubitsch, concordance between "De los hermanos," mm. 1-4.

output, it would be reasonable to expect the converse, that elements of his contemporary writings "crept" into his tangos.

Examples of stylistic blending between tango and new music appear throughout the composer's work; however, they are rarely more evident than in "De los hermanos." The piece's initial section (mm. 1-16) exhibits unmistakable minimalist influences. The overall symmetry of the texture, which evolves from the manipulation of a few repeated melodic cells (see fig. 7), points directly to Gubitsch's interest in the compositional techniques of Steve Reich and Philip Glass. Beyond the repetitive nature of the pulse-driven texture (a characteristic that defines a large portion of Glass's oeuvre), the influence seems further emphasized by modality and by the out-of-phase effect achieved by the juxtaposition of cells of dissimilar melodic contour in the piano and guitar-a technique characteristic of 1960 minimalism.

In figure 7, we can see that the tightly woven texture that defines the piece's opening section results from the manipulation of a few related melodic cells. These are all of equal length (six sixteenth-notes) and follow five times over a two-measure period. A tag of two sixteenth-notes is added to complete the two-measure cell.

The abbreviations used in figure 7 attempt to show the relationships between the cellular components. In this way, G1' (guitar 1') is seen as a variant of G1 (guitar 1). Similarly, PR1' (piano right 1') is understood as an elaboration of PR1 (piano right 1). Naming the initial piano cell as PL1/PLiC (piano left 1 / piano left 1 complement) shows the cell to be a compound one, a miniaturized antecedent/consequent phrase.

The pulse that drives the composition is set from the start by the reiteration of G1. At the same time, the particular design of this cell, in conjunction with its rate of repetition, shapes the 3-3-3-3-3-1 rhythmic framework of the opening section. With the entrance of the piano accompaniment in measure 3, the texture clearly changes. Metrically, both cells ( $\mathrm{G}_{1}$ and $\left.\mathrm{PL}_{1} / \mathrm{PL} 1 \mathrm{C}\right)$ line up. However, the differences between their contours and the complete cell's rate of repetition alter the previously established sense of pulse and direction. The compound structure of $\mathrm{PL}_{1} / \mathrm{PL}_{1} \mathrm{C}$ determines that the cell will repeat itself 2.5 rather than five times. Hence, under the $3-3-3-3-3-1$ established by $\mathrm{G} 1$, $\mathrm{PL} 1 / \mathrm{PL} 1 \mathrm{C}$ accentuates a quarter-note level 3-3-2 scheme reinforced by the first, third, and fifth articulation of G1 (see fig. 8). 

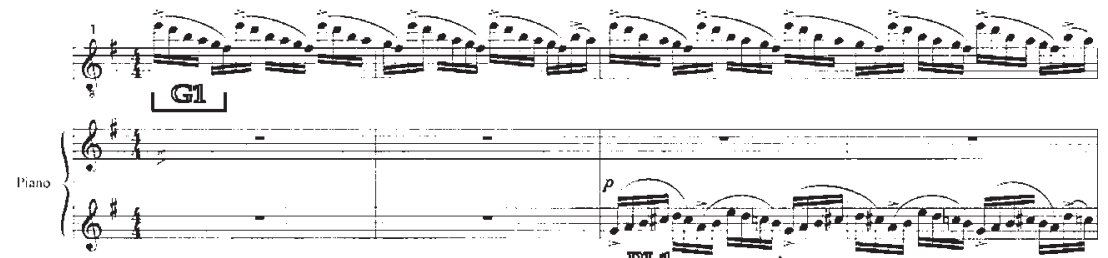

$\mathbb{P L 1}=\mathbb{P L I C}$
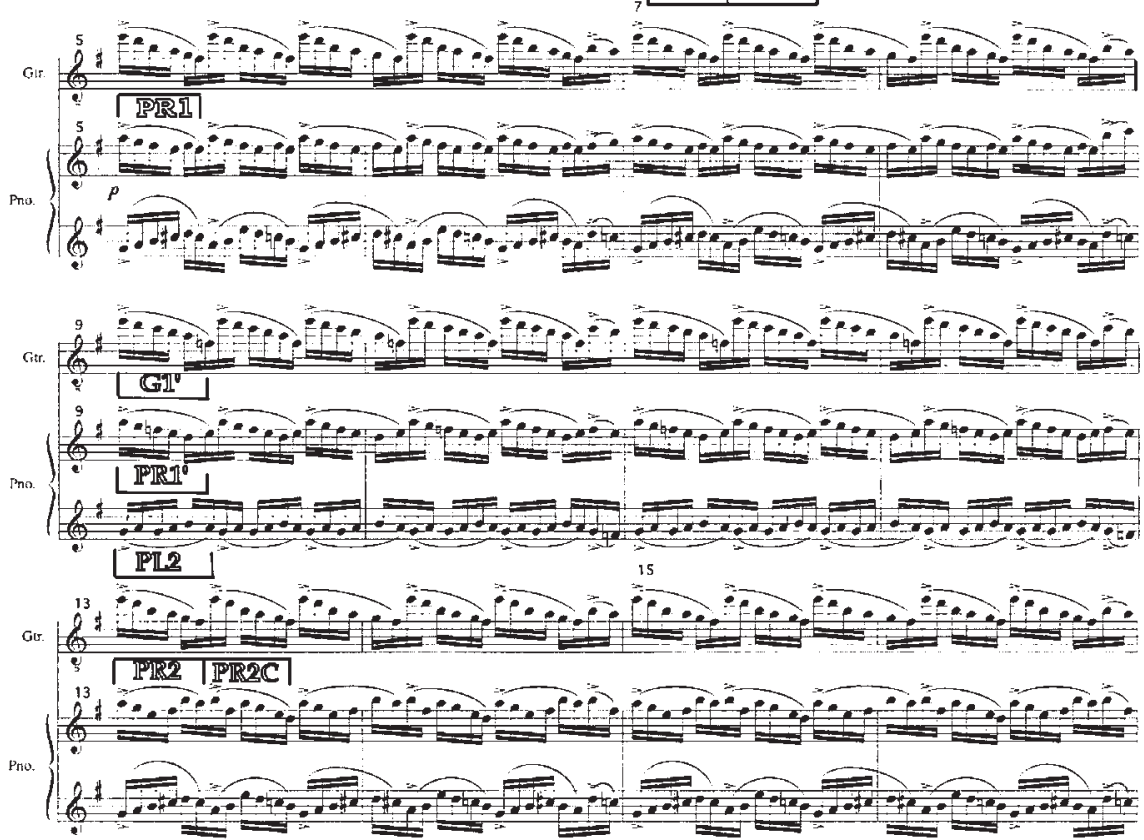

Figure 7. Tomás Gubitsch, "De los hermanos," mm. 1-16

In measure 5, the entrance of the right-hand piano part completes the threevoice texture of the accompaniment. As a result of its length, equal to that of $\mathrm{G} 1$, the introduction of $\mathrm{PR} 1$ reinforces the $3-3-3-3-3-1$ subdivision. However, as happened before, PR1 also accentuates, through its first, third, and fifth statements, the underlying 3-3-2 scheme. In measure 9 a final change is introduced to enhance a modulation to $\mathrm{F}$ Lydian. $\mathrm{PL}_{2}$ replaces $\mathrm{PL}_{1} / \mathrm{PL}_{1} \mathrm{C}$ and dissolves the previous metric tension. The pace is now set by the sole articulation of the 3-3-3-3-2-2 subdivision. Interestingly, the texture is further lightened by the trill-like design of PL2. The perceived sense of acceleration disappears two measures later. With a modulation to E minor, in measure 13 , the metric tension returns.

\section{FRENCH IMPRESSIONISM}

If the features described above point to Reich and Glass's minimalism, the melodic design, harmonic development, and overall structure of "De los hermanos" point to another of Gubitsch's compositional interests: French impressionism. 


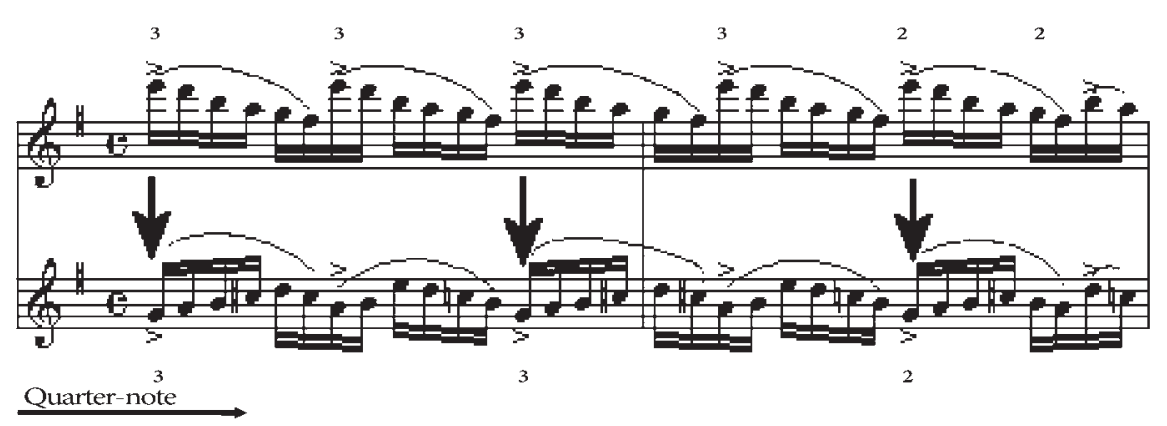

Figure 8. Metric concordance between G1 and PLC/PLC1.

Tango composers in the 196os and 1970s have commented often on the influence that the sounds of fin de siècle France had on their sonic conceptualizations of tango. In practice, the influence materialized most commonly in the appropriation of a particular chord, a non-traditional harmonic progression, or a cadential formula. In Gubitsch's case, however, the relationship goes far beyond the incorporation of isolated elements.

Further examination of the initial sixteen-measure section of "De los hermanos" establishes a correlation with Maurice Ravel's "Le Tombeau de Couperin," a piece clearly representative of French Impressionism.

The textural resemblance between the prelude of "Le Tombeau de Couperin" and Gubitsch's opening section in "De los hermanos" is unmistakable. Both are introductory segments, the tempo markings are similar (a difference of less than $20 \mathrm{bpm}$ ), and the pitch collections that define the initial sections of each work are almost identical. Gubitsch's segment opens with a hexachordal collection (E-F\#-G-A-B-D) only one pitch removed from the pentatonic design of Ravel's segment (E-G-A-B-D). Furthermore, as shown in figure 9, the juxtaposition of the initial measures of both pieces shows that despite their dissimilar metric arrangements (common time versus 12/16) they could both be interpreted as being "in phase" with one another.

Although only the first descending second of Gubitsch's pattern parallels Ravel's famous design, the relationship between the two is solidified by their pitch similarity (see circled notes in fig. 9) and by the contour correlations established in the piano line. The graphed concordances presented in figure 6 also show a similar rate of motion.

The impressionist influence can be heard as well in Gubitsch's non-traditional harmonic treatment. The tonal centre of the piece, E minor, is initially suggested by the pitch content of the repeated melodic pattern, but this is never really secured by traditional cadential formulas. The first real appearance of the dominant, introduced in measure 25 , is simply the dominant root sounded in three different octaves (see fig. 10).

Such a sparse voicing is not particularly unusual, nor is it tied to a specific style. If it is appropriately worked out, the sound of the dominant root alone would secure the expectation of motion toward a resolving tonic. However, what stands out in this instance is the composer's subsequent manipulation of 


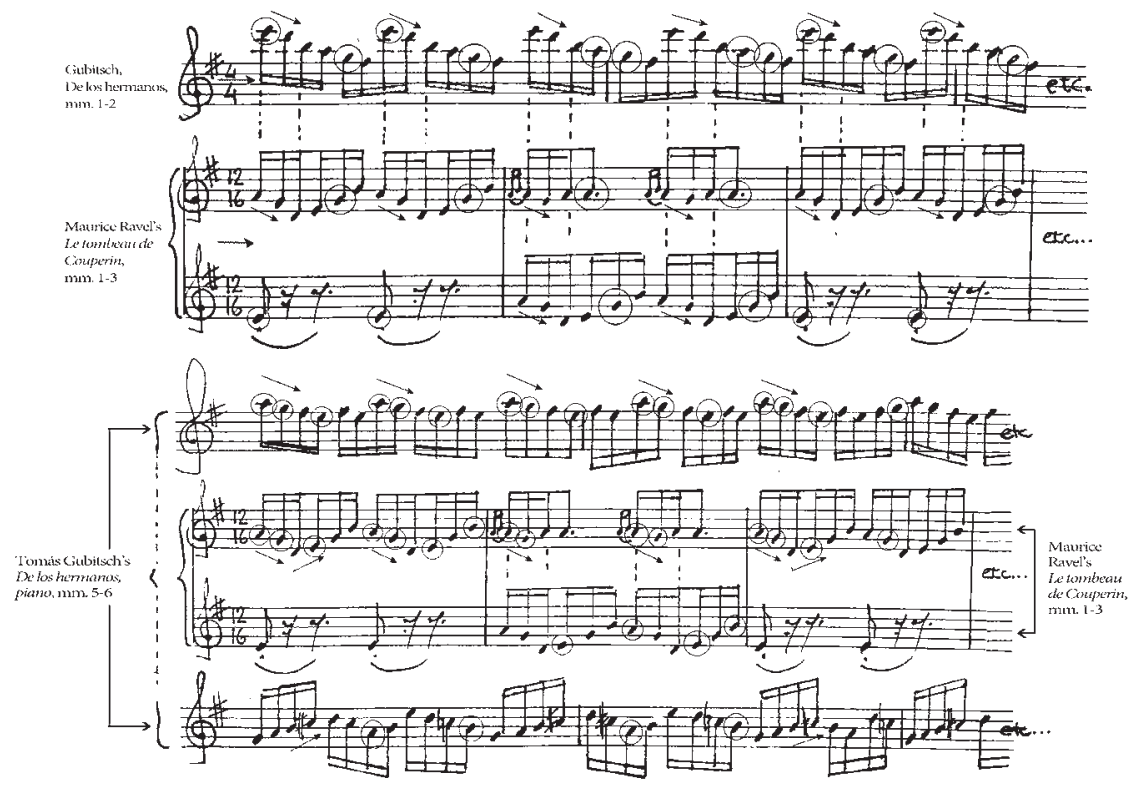

Figure 9. Contour and pitch concordances between the openings of Tomás Gubitsch's "De los hermanos"” and Maurice Ravel's "Le Tombeau de Couperin".

the pitch that, in theory, is required for "properly" securing E minor as home key: the key's leading tone, D-sharp. As musicologist Donald F. Tovey wrote, "You cannot assert a key without giving its dominant chord" (Tovey 1928, 344; italics mine). The dominant here, however, is not expressed harmonically but rather as a root with doublings, the leading tone not sounded. D-sharp does finally appear, but not as the third of $\mathrm{B} 7$, the dominant. The pitch is introduced later as the root of a major seventh chord enharmonically spelled as E-flat (see fig. 11, m. 31).

Through such meticulously manipulated elisions of cadential resolutions, Gubitsch lightens the intricate texture of the piece, propelling its momentum forward. The chromatic shift from E minor to E-flat major that occurs in measure 31 (see fig. 11) is short lived, but it assumes larger significance when one considers other chromatic relationships that appear throughout the work. The opening section evolves by contrasting two sonorities whose relationship, as established in the composition, finds no basis in functional harmony. E minor and F Lydian could be tied to $\mathrm{C}$ major, but in this case they are handled as two contrasting pitch collections with no ties to a common tonal centre.

Minor second relations, introduced initially by the modulation from E minor to F Lydian, become increasingly relevant as the piece progresses. The initial ascending chromatic shift (E minor to F Lydian) is later mirrored by the shift from E minor to E-flat major that underlies the piece's main melody (see fig. 11, m. 31). Minor seconds are also recurrently found in the intervallic structure of the voicing used by Gubitsch to harmonize the piece's main theme (see fig. 12). 


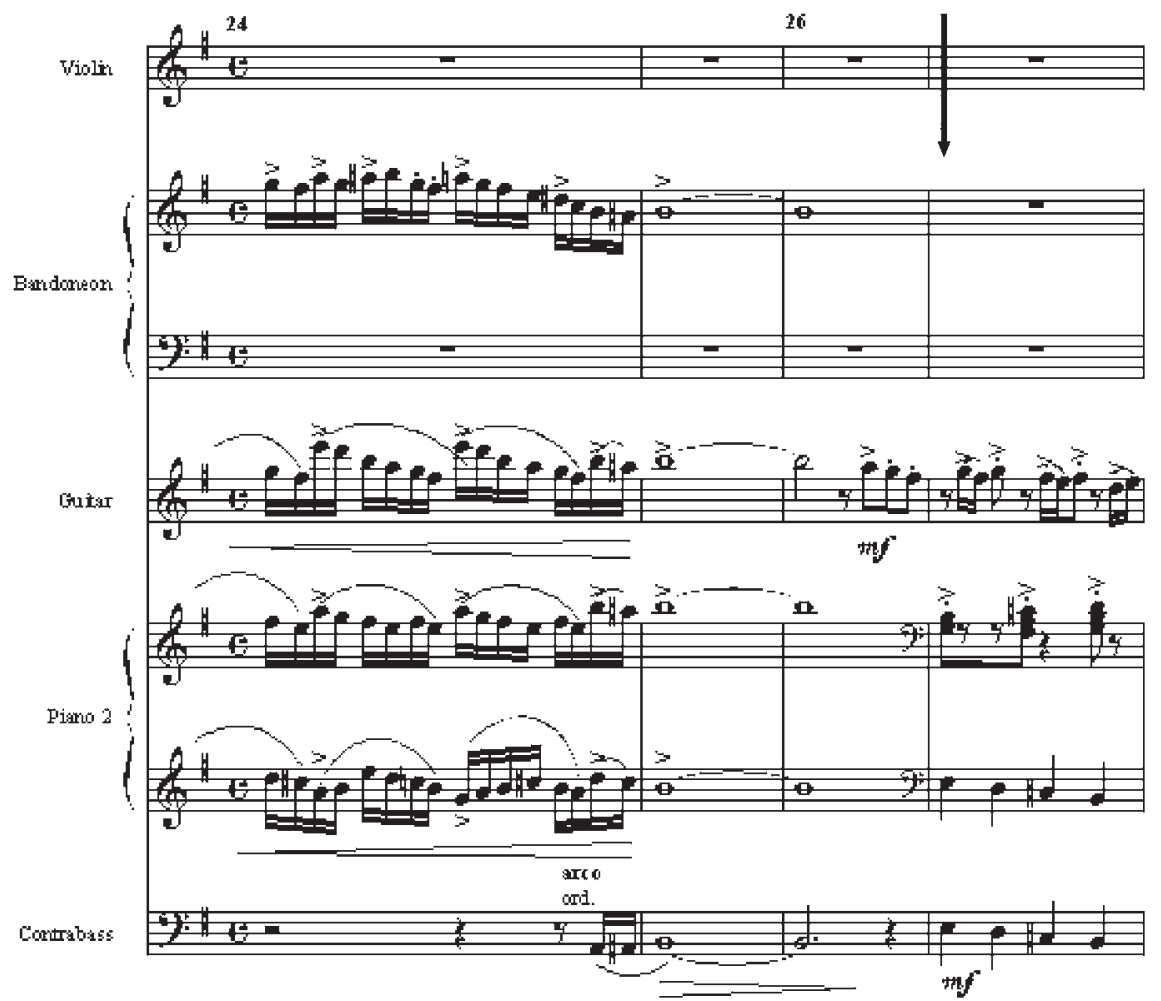

Figure 10.Tomás Gubitsch, "De los hermanos," mm. 24-27.

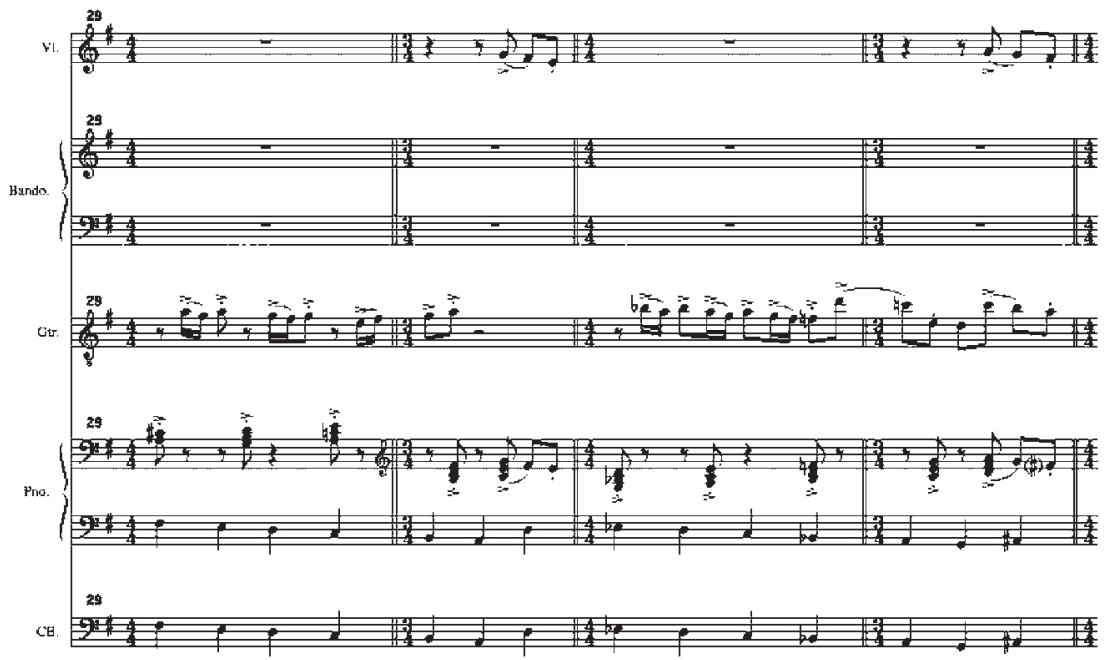

Figure 11. Tomás Gubitsch, "De los hermanos," mm. 29-32 
To return to impressionism, the minor ninth chord, frequently used by Gubitsch to harmonize melodic components of the main theme, is used with considerable frequency by Ravel. For example, it appears in arpeggiated form during the Prelude from "Le Tombeau de Couperin" (see figs. 13.1 and 13.2) and as a chordal construction in the closing toccata of the piece (see fig. 13.3).

In fact, in his famous analysis of Ravel's piano works, Olivier Messiaen refers to the use of the natural ninth over a minor seventh chord as "la neuvieme Ravélienne" (Messiaen and Loriod-Messiaen 2003, 88). As a chord, the sonority is treated by both Gubitsch and Ravel in a similar manner (see figs. 12 and 13.3). Additionally, Gubitsch conspicuously uses minor seconds in the bass part to join the $3 / 4$ and $4 / 4$ segments that form the metric structure of the piece's main

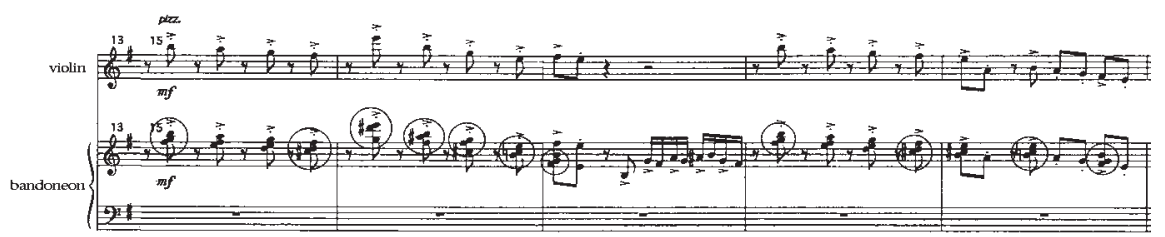

Figure 12.Tomás Gubitsch, "De los hermanos," minor seconds in the voicing structure of the main theme's harmonization.

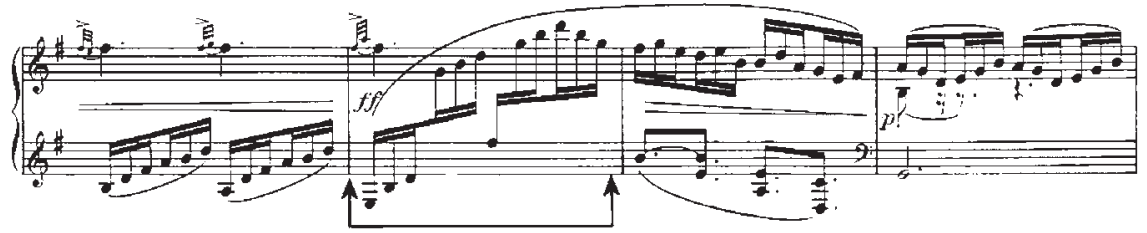

Figure 13.1. Maurice Ravel, Prelude from “Le Tombeau de Couperin,” mm. 27-30.

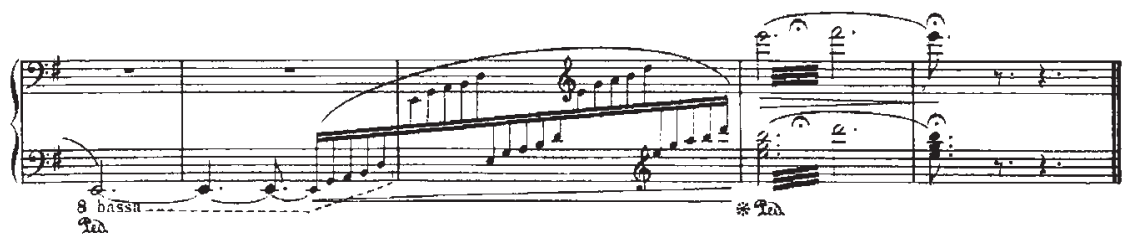

Figure 13.2. Maurice Ravel, Prelude from "Le Tombeau de Couperin," mm. 93-97.

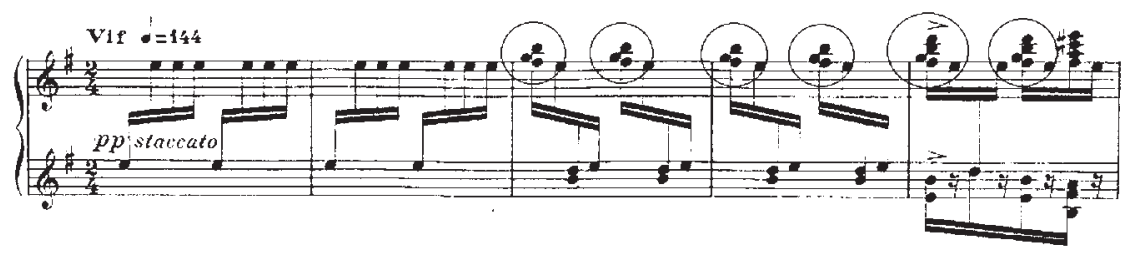

Figure 13.3. Maurice Ravel, “Toccata” from Le Tombeau de Couperin, mm. 1-5.

Figure 13. Maurice Ravel, “Le Tombeau de Couperin,” minor ninth chords. 
phrase (see circled notes in fig. 14). A final impressionistic touch can be found in the overall asymmetry of the composition's formal scheme.

Double Bass
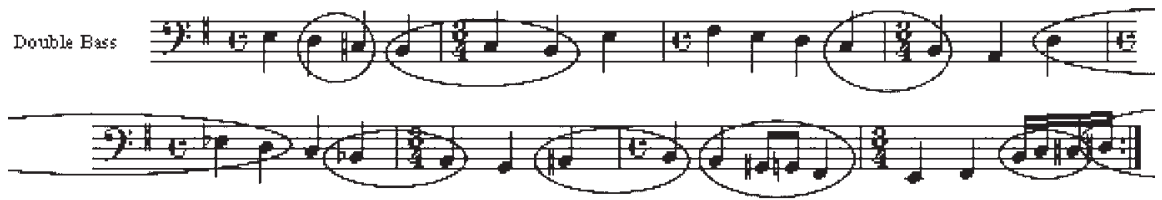

Figure 14. Tomás Gubitsch, "De los hermanos," minor seconds in the bass line, mm. 27-34.

\section{Rock}

I will conclude my analysis of hybridization in Tomás Gubitsch's compositions with a discussion of rock, perhaps the musical influence that is closest to Gubitsch's heart. Gubitsch is certainly not the first composer who has attempted to find common ground between tango and rock-two seemingly irreconcilable traditions. In 1975, clearly influenced by American jazz-fusion movement of the early 1970s (for example, the groups Return to Forever, Weather Report, and the Mahavishnu Orchestra), Astor Piazzolla formed his first Octeto Electrónico (electronic octet) and made what was probably the first attempt to bridge tango and rock. In 1976, Piazzolla described his perception of rock: "Today the music of Buenos Aires needs to be related to that 'noise,' to that music" (qtd. in Azzi and Collier 2002, 326). In hindsight and despite the relative strong acceptance that Piazzolla's project had at the time, the experience was not a particularly successful one. In October 1978, during an interview for Buenos Aires's Clarin magazine, Piazzolla stated that, in relation to his electronic period, he felt he had "failed completely." The harsh self-criticism may be in part a result of the circumstances that surrounded the breakup of his second electronic octet earlier that year. Nonetheless, when one listens to Piazzolla's "electronic" ensembles within the context of the composer's whole oeuvre, one begins to understand Piazzolla's disenchantment. The experience leaves the listener feeling that the music of the electronic ensembles has been forcefully divested of the textural, melodic, and rhythmic nuances that made his acoustic ensembles shine.

The dialogue between rock and tango has been quite different in Gubitsch's case, and understandably so. Gubitsch not only belongs to the generation that saw the rise of rock nacional in Argentina but was actively involved in the genre. During an informal public debate on the directions of current tango, Gubitsch recalled, "I was a kid who played rock"15 (Manso 2006). It is important to keep in mind that the 1970s were the guitarist's formative years, and Buenos Aires was certainly not immune to the revolutionary social, cultural, and musical changes that characterized the late 1960 s in North America. In a recent interview, Martin Matalon, another Argentine composer who has resettled in Paris,

15 "Yo era un pibe que hacia rock." 
referred to rock: "It was the music I used to listen to; the one which interested me the most. Not any longer. That's, in a way, in the past. Now, I believe that rock got stuck repeating its elements. Regardless, as it was relevant to our formative years, it informs, although inconsistently, our conception of music" (Fisherman 2008). ${ }^{16}$

In addition to the rock orientation signalled by the prominent positioning of his electric guitar, mentioned at the outset of this analysis, the rock influence in Gubitsch emerges most clearly from the articulation of the guitar. It is most noticeable in the riff-like melody of "Te acordás de mí?," which is undoubtedly "guitaristic"; it is highly symmetric, pentatonic sounding, and harmonized in fifths. Rock's influence can also be identified in the abrupt insertion of unexpected material within Gubistch's compositions. Sudden textural changes with no previous preparation, for example, are characteristic of "De los hermanos." In addition, measure-long chains of consecutive fourths or diminished arpeggios emerge abruptly during the piece. Interestingly, Eric Charlán, the quintet's double bass player, has designated the composition as a "Tango Zappatista" in reference to Frank Zappa, the superb guitarist and prolific composer whose highly eclectic music was characterized by the unexpectedness of its turns and the abruptness of some of its changes (Bernard 2000).

\section{Conclusion}

Tomas Gubitsch is but one example of numerous musicians who in the last several years have been experimenting with new ways of using tango as a medium of expression. Using his personal musical interests-including jazz, classical music, new music, minimalism, French impressionism, and rock-and working from his Paris residence, Gubistch has produced music that resonates, albeit in different ways, with both European and Argentine audiences.

As we have seen in this paper, hybridization has allowed tango to move beyond the limits of its previous semantic domain, creating a new space of signification. In fact, if the interest for tango as a musical tradition has not vanished it is because the genre has, in the hands of composers, musicians, and producers around the globe, developed the mechanisms to adapt to increasingly complex needs for representation. In a way, the current broadening of tango's conceptualization brings this story of cross-cultural exchanges and hybridization to a full circle. Now, after more than a century, dialogues similar to those responsible for tango's conception are, once again, shaping the new forms and sounds the genre is assuming.

Despite the novel textures that Gubitsch crafted through hybridizing these many elements, the elusive character that allows listeners to identify the final sonic product as tango, remains seemingly unperturbed. In this respect, my analysis has initially pointed towards Gubitsch's masterful manipulation of a

16 "Era la música que escuchaba; la que más me interesaba. Ahora no, eso quedó un poco en el pasado. A mí, ahora, me parece que el rock se quedó repitiendo cosas. Pero, seguramente, como eso tuvo que ver con los años de formación, aunque sea inconscientemente forma parte de nuestra idea de la música." 
series of metric schemes directly associated with Astor Piazzolla. Unquestionably, Gubitsch's ability to dissolve previous boundaries without leaving the listeners wandering in a stylistic maze speaks volumes about his compositional skills and acute musical sensibility. Stylistically, however, this phenomenon seems indicative of an inherent stylistic malleability in the tango genre itself that needs to be further studied.

\section{REFERENCES}

Azzi, Maria Susana, and Simon Collier. 2002. Astor Piazzolla: Su Vida y Su Música. Buenos Aires: Editorial El Ateneo.

Bakhtin, Mikhail. 1981. Dialogic imagination: Four essays. Edited by Michael Holoquist and translated by Caryl Emerson and Michael Holoquist, 259422. Austin: University of Texas Press.

Bent, Ian D., and Anthony Pople. 2008. "Analysis." Oxford Music Online, http:// www.oxfordmusiconline.com.ezproxy.library.yorku.ca/subscriber/article/ grove/music/41862.

Berliner, Paul. 1994. Thinking in jazz: The infinite art of improvisation. Chicago: University of Chicago Press.

Bernard, Jonathan. 200o. The musical world(s?) of Franck Zappa: Some observations of his "crossover" pieces. In Expression in pop-rock music: A collection of critical and analytical essays, edited by Walter Everett, 157-210. New York: Garland.

Bhabha, Homi. 1994. The location of culture. London: Routledge.

Brunelli, Omar Garcia, ed. 2008. Estudios Sobre la Obra de Astor Piazzolla. Buenos Aires: Gourmet Musical Ediciones.

Cadicamo, Enrique. 1975. La Historia del Tango en Paris. Buenos Aires: El Corregidor.

Canclini, Néstor Garcia. 1995. Hybrid cultures. Translated by L. Chiappari and S. Lopez. Minneapolis: University of Minnesota Press.

Carretero, Andres. 1999. Tango, Testigo Social. Buenos Aires: Ediciones Continente.

Cibotti, Ema. 2008. Del Encanto al Desencanto de una Elite, en Clave de Tango. In Escritos Sobre Tango: En el Río de la Plata y en la Diáspora, edited by Teresita Lencina, Omar García, Brunelli, and Ricardo Salton, 41-54. Buenos Aires: Centro Feca Ediciones.

Collier, Simon. 1992. The popular roots of the Argentine tango. History Workshop 34:92-100.

Denniston, Christine. 2007. The meaning of tango: The story of the Argentinean dance. London: Portico.

Fisherman, Diego. 2008. Martin Matalon se presenta en Buenos Aires, la tradición reinterpretada. Página12, 23 August. http://www.pagina12.com.ar/ diario/suplementos/espectaculos/3-11023-2008-08-23.html.

Frello, Birgitta. n.d. Essentialism, hybridism and cultural critique. Centre for Cultural Studies Research. http://www.uel.ac.uk/ccsr/documents/ FrelloEssentialism.pdf. 
Garramuño, Florencia. 2007. Modernidades primitivas: tango, samba y nación. Buenos Aires: Fondo de Cultura Económica.

Gitler, Ira. 1958. Trane on the tracks. Down Beat, 16 October, 16-17.

Guilbault, Jocelyne. 2005. Audible entanglements: Nation and diasporas in Trinidad's calypso music scene. Small Axe 17:40-63.

Humbert, Béatrice. 2000. El Tango en París de 1907 à 1920. In El Tango Nómade: Ensayos sobre la Diáspora del Tango, edited by Ramón Pelinski, 99-162. Buenos Aires: El Corregidor.

Kapchan, Deborah, and Pauline Turner Strong. 1999. Theorizing the hybrid. Journal of American Folklore 112 (445): 239-53.

Kohan, Pablo. 2002. Tango. Diccionario de la Música Española e Hispanoamericana 10:142-55. Madrid: Sociedad General de Autores y Editores.

Lamas, Hugo, and Enrique Binda. 1998. El Tango en la Sociedad Porteña (18801920). Buenos Aires: Héctor Lorenzo Lucci Ediciones.

Luker, Morgan James. 2007. Tango Renovación: On the uses of music history in post-crisis Argentina. Latin American Music Review 28 (1): 68-93.

Manso, Diego. 2006. ¿Como sigue el tango? Clarín, 14 October.

Matamoro, Blas. 1971. Historia del Tango. Buenos Aires: Centro Editor de América Latina.

Mauriño, Gabriela. 2001. Raíces tangueras de la obra de Astor Paizzolla. Latin American Music Review 22 (2): 240-54.

Messiaen, Olivier, and Yvonne Loriod-Messiaen. 2003. Ravel: Analyses des œuvres pour piano de Maurice Ravel. Paris: Durand.

Nederven Pieterse, J. 1995. Globalization as hybridization. In Global modernities, edited by Mike Featherstone, Scott Lash, and Roland Robertson. London: Sage.

Pelinski, Ramón, ed. 20ooa. El Tango Nomade: Ensayos sobre la diáspora del tango. Buenos Aires: El Corregidor.

- 20oob. Invitación a la Etnomusicología: Quince Fragmentos y un Tango. Madrid: AKAL.

- 2008. Tango Nomade: Una Metafora de la Globalizacion.” In Escritos Sobre Tango: En el Río de la Plata y en la Diáspora, edited by Teresita Lencina, Omar García, Brunelli and Ricardo Salton, 65-128. Buenos Aires: Centro Feca Ediciones.

Roden, Christina. n.d. Christina Roden talks with Tomas Gubitsch: The multifaceted musician/producer discusses an immigrant's life in music. Rootsworld. http://www.rootsworld.com/interview/gubitsch.html.

Sarlo, Beatriz. 1999. Una modernidad periférica: Buenos Aires 1920-1930. Buenos Aires: Nueva Visión.

Savigliano, Marta. 1995. Tango and the political economy of passion. San Francisco: Westview Press.

Stokes, Martin. 2004. Music and the global order. Annual Review of Anthropology 33:47-72.

Stokes, M., C. Pegg, H. Myers, and P. V. Bohlman. 2010. Ethnomusicology. Oxford Music Online, http://www.oxfordmusiconline.com.ezproxy.library. yorku.ca/subscriber/article/grove/music/52178. 
Thompson, Robert Farris. 2005. Tango: The art history of love. New York: Vintage Books.

Tovey, Donald Francis. 1928. Schubert number. Music and Letters 9 (4): 341-63. Vega, Carlos. 2007. Estudios para los orígenes del tango Argentino. Buenos Aires: Editorial de la Universidad Católica Argentina.

Vila, Pablo. 1989. Argentina's "rock nacional": The struggle for meaning. Latin American Music Review 10 (1): 1-28.

Weiss, Sarah. 2008. Permeable boundaries: Hybridity, music, and the reception of Robert Wilson's I La Galigo. Ethnomusicology 52(2): 203-38.

Young, Robert. 1995. Colonial desire: Hybridity in theory, culture and race. London: Routledge.

Zalko, Nardo. 2001. Paris-Buenos Aires: Un Siglo de Tango. Buenos Aires: El Corregidor.

\title{
DisCOGRAPHY
}

Gubitsch, Tomas. 2006. 5. Acqua Records, AQ 115.

\begin{abstract}
Tango's recent resurgence has greatly intensified the momentum of a long process of "international dissemination" that began with the genre's arrival in Paris during the first decade of the twentieth century. The many dialogues promoted by this renewed popularity have set the stage for an unprecedented period of development marked by artistic collaboration, experimentation, and hybridization. As a result, the genre is undergoing numerous changes; among the most striking are the new sonic shapes it is assuming. Through the detailed analysis of two compositions by Argentine guitarist and composer Tomás Gubitsch, who since the 1970s-the time of the country's notorious and brutal "Dirty War"-has resided in Paris, this paper examines some of the processes currently shaping the sonic form of some of tango's numerous variants. This work hopes to shed light on Gubitsch the composer and on the current tango phenomenon itself, as well as to contribute to a better understanding of the ways musical hybrids are constructed.
\end{abstract}

\section{RÉSUMÉ}

La récente recrudescence du tango a considérablement intensifié le rythme d'un long processus de «diffusion internationale» qui commence avec l'arrivée du genre à Paris pendant la première décennie du $\mathrm{XX}^{\mathrm{e}}$ siècle. Les nombreux dialogues engendrés par ce regain de popularité ont préparé le terrain pour une période de développement sans précédent marquée par la collaboration artistique, l'expérimentation et l'hybridation. En conséquence, le genre subit de nombreux changements, les nouvelles formes sonores qu'il revêt parmi les plus frappants de ceux-ci. À travers une analyse détaillée de deux compositions du guitariste et compositeur argentin Tomás Gubitsch, le présent document examine quelques-uns des processus qui façonnent actuellement la forme sonore de nombreuses variantes du tango. Ce travail devrait permettre de faire la lumière sur Gubitsch le compositeur et sur le phénomène présent du tango lui-même, ainsi que de contribuer à une meilleure compréhension des façons dont se construisent des hybrides musicaux. 